\title{
Perceptions of transformational leadership (TFL) style: A study on Malaysian cooperative board of directors
}

\author{
Hezlina binti Mohd Hashim ${ }^{1 *}$, and Ahmed Razman bin Abdul Latiff \\ ${ }^{1}$ Dept. of Management \& Humanities, Universiti Teknologi PETRONAS,32610 Seri Iskandar, Perak \\ ${ }^{2}$ Putra Business School, Universiti Putra Malaysia, 43400 Serdang,Selangor
}

\begin{abstract}
This paper is a pilot study that examines the perceptions of transformational leadership among cooperative movements' boards. Past studies have shown that transformational leadership is a strong predictor of firm performance (effectiveness). This study aims to examine on the perceptions of transformational leadership style among Malaysian cooperatives board of directors. Among the major problems faced by Malaysian cooperatives are the lack of board of directors' commitments, directors failed to perform their duties effectively and weak leadership from Board of Directors which affected the board effectiveness and performance.
\end{abstract}

\section{Introduction}

The Eleventh Malaysia Plan (2016-2020) has stated that the government will support cooperativebased community enterprises through incentives on funding and facilities as well as leadership and management programs (Economic Planning Unit, 2015).. The government has recognized the significance of cooperatives in contributing towards Malaysian economy as well as helping Malaysia to become a developed country by 2020. Furthermore, Malaysian cooperatives have been recognized as the third economic sector with a target income of RM50 billion by 2020 (Tulus \& Iyer, 2015). It is in line with the 2011-2020 National Cooperative Policy (NCP) launched by Prime Minister Datuk Seri Najib Tun Razak in Malaysia which verified and acknowledged the cooperative movement's role in economic development.

Malaysian largest cooperative bank, Bank Kerjasama Rakyat Malaysia, was ranked the $118^{\text {th }}$ position in the world's largest cooperative ranking (Yusof, 2017). Malaysian cooperatives in general did not perform well compared to other cooperatives globally with total turnover in 2013 at only USD 3.74 billion compared to other developing countries such as Republic of Korea (USD 63.29 billion), Brazil (USD 45.47 billion), Colombia (USD 5.73 billion and India (USD 4.24 billion) (World Cooperative Monitor, 2015). Although the second NCP is important as it is consistent with the $2010 \mathrm{New}$ Economic Model to progress to the next level of development as a high-income nation from Malaysia's current middle-income status, the increase in number of cooperatives is inverted with the growth of membership, share capital and assets had decreased (Tulus \& Iyer, 2015). Table 1 shows the decrease in the number of membership from the Year 2015 to the Year 2017 according to clusters in Malaysian cooepratives:

Table 1. Number of membership according to clusters as of 30 June 2017

\begin{tabular}{|c|c|c|c|c|}
\hline No & Cluster & \multicolumn{3}{|c|}{ Year } \\
\hline & & $\mathbf{2 0 1 5}$ & $\mathbf{2 0 1 6}$ & $\mathbf{2 0 1 7}$ \\
\hline 1 & Large & $2,912,869$ & $2,530,009$ & $2,820,163$ \\
\hline 2 & Medium & 854,798 & 551,175 & 687,247 \\
\hline 3 & Small & 857,870 & 858,476 & 838,344 \\
\hline 4 & Micro & $2,792,482$ & $3,085,467$ & $2,388,034$ \\
\hline & Total & $\mathbf{7 , 4 1 8 , 0 1 9}$ & $\mathbf{7 , 0 2 5 , 1 2 7}$ & $\mathbf{6 , 7 3 3 , 7 8 8}$ \\
\hline
\end{tabular}

Source: Malaysian Cooperative Societies Commission (2017)

\footnotetext{
*Corresponding author: hezlina_hashim@utp.edu.my and razman@putrabs.edu.my
} 
The decrease in the membership number is very worrisome. There is a decrease of 302,892 members from 2015 to 2016 and a decrease of another 291,339 members from 2016 to 2017. If the number continues to decrease continuously, there might be a lot of closures in cooperative movements. What will happen if all researchers just ignore this issue and focus to study on other sectors such as private and public sectors? The problem may escalate and cause financial losses which will lead to cooperatives closures. As the third contributor to Malaysian GDP with a target income of RM50 billion by 2020 , the decrease of membership is a serious issue if no action is taken to improve it. The decrease shows that members are starting to lose confidence in cooperatives and hence, withdraw themselves from being members in the cooperatives. The withdrawal of these members will also mean that the will bring their shares or membership fees out from the cooperatives. Therefore, the decrease in the number of membership cooperatives is a serious indicator signaling that some actions must be taken to ensure the profitability and sustainability of the business is secured.

Corporate boards today are expected to be more engaged, more knowledgeable and more effective than in the past. The importance of positive leadership as a determinant of board effectiveness is well recognized. However empirical research on board leadership is rather limited except for those studies that focus the attention on the benefits of combining or separating the roles of chief executive officer (CEO) and chair (Bass \& Riggio, 2006). Transformational leadership (TFL) refers to a leadership approach that is based on visions and empowerment that causes a change in individuals and social systems to obtain exceptional performance (Tafvelin, 2016 \& Bass, 1998). However, the functionality of TFL has exposed a considerable conceptual gap (Yukl, 1999 \& Avolio \& Yammarino, 2002). It is somehow surprising that the dynamic and contextual transformation perspective of TFL is underdeveloped. Scholars found that it is unclear regarding the practicality of leaders' behaviors and the way they affect firm performance (Avolio \& Yammarino, 2002 \& Humphreys \& Einstein, 2003). Despite the fact that TFL is not a new model and could be found in the works of earlier management theorists such as (Humphreys \& Einstein, 2003 \& Mahalinga Shiva \& Suar, 2012), there are still some key parts of TFL which need to be examined. This study, therefore, aims to study on the perceptions of transformational leadership style among Malaysian cooperatives board of directors.

\section{TFL and culture}

TFL has also been studied concerning on culture. In a qualitative study involving 10 staff and faculty members of a top Lebanon university, (Yukl, 1989) indicated that the director significantly displayed the characteristics that define a transformational leader, except nepotism and lower level employees who were not involved in the decision-making process. The author emphasized the possibility of transferring the TFL's success to the Middle-Eastern society with different norms and values (culture) from the North-American context. Another study by (Bass, 1994) stated that TFL indirectly gave impact to non-governmental organizations effectiveness by promoting organizational culture.

\subsection{Effect OF TFL}

Transformational leadership is defined as a leadership style that will transform the norms and values of employees while motivating them to perform beyond their expectations (Pieterse-Landman, 2012). The highlight on intrinsic motivation and positive improvement of followers has made transformational leadership to become more attractive compared to the process of transactional leadership (Tafvelin, 2016). TFL not only inspires and guides followers through uncertain environments but also empowers them to perform their tasks effectively. The transformational leader will focus on the followers' improvement related to organizational goals which will4lead to job commitment and improve organizational performance (Pieterse-Landman, 2012).. The transformational leader will focus on the followers' improvement related to organizational goals which will lead to job commitment and improve organizational performance (Yaghoubipoor \& Ahmed, 2013). Transformational leadership not only inspires and guides followers through uncertain environments but also empowers them to perform their tasks effectively. Many TFL studies were done to investigate the effects on followers or employees. Mesterova, Prochazka \& Vaculik et al. (2015) surveyed 100 employees working in the industry and service sectors in France and found that there is a partial relationship between TFL and follower task performance on the one hand and between TFL and follower perceptions of core job 
characteristics on another hand. The empirical evidence linking French leader behaviors in Northern France and Paris and its suburbs and employees' perceptions of their jobs was highlighted. (Colbert \& Bradley, 2014) analyzed the datagathered from 540 production line employees in Iran's automobile industry using structured equation modeling. Different employee job satisfaction components were found to give impact in different ways depending on the leadership style. The dominant leadership style practiced in Iran's automobile industry is discovered to be the transformational style.

The effectiveness of TFL has been proven by many researchers from their studies. Sarver \& Miller, (2014) has demonstrated positive relationship between TFL and firm effectiveness. Rather than using proxy variables from archival sources or demographic data as done by many other scholars, using direct measures of personality and leadership resulted in the mean levels of conscientiousness of the top management team members and chief executive officer both directly related to organizational performance (Birasnav, 2014). Further,it is also found that organizational performance was higher when the chief executive officer exhibited higher levels of transformational leadership.

Transformational leaders have always been associated with having positive and inspiring characters. A study on 161 police chiefs in Texas conducted found that the police chiefs were consistently ranked as the most effective transformational leaders across leadership styles (Mason, Griffin, \& Parker, 2014). The author stressed that transformational leaders are characterized as confident, energetic, and open-minded. A study using systematic literature review technique to examine the link between TFL and manufacturing strategies found that top-level leaders displayed TFL behaviors while implementing manufacturing strategies in their firms which also influence cost reduction was done (Chen, Bian, \& Hou, 2015). It was found that transformational leaders effectively perform change management process through achieving a vision for future by influencing their employees. Elsewhere, in a survey on 56 leaders taking part in a one-year TFL training program, discovered that leaders whose psychological attributes of SE, perspective taking and positive affect increased over the training period also reported improvements in their TFL behavior (Boehm, Dwertmann, Bruch, \& Shamir, 2015).

\subsection{Effect on performance}

Scholars have used TFL as a mediator or moderator in their studies. The benefit of emotional intelligence on positive work psychology in a non-western culture context is confirmed (Brouer, Chiu, \& Wang, 2016). Perceived leader's TFL was found to positively moderated the relationship between subordinate's emotional intelligence and work performance. Feng, Huang, \& Zhang, 2016) stated that both organizational identity strength and TFL fully mediate the potential impact of chief executive officer charisma on firm performance. In a different study, social wisdom was positively related to leader charisma, individualized consideration, and intellectual stimulation while interpersonal influence was related to leader charisma and intellectual stimulation (Tabassi, Ramli, Bakar, \& Pakir, 2014). The results supported that TFL mediates the relationship between the leader political skill and follower performance.

\subsection{Effect on team performance}

In the context of team performance, a survey on full-time employees working in groups in 43 companies scattered in five cities in China concluded that TFL was positively related to innovative group behaviors which later affected the performance (Sun, Xu, \& Shang, 2014). Rao \& Abdul (2015) stated TFL factors in the model had shown high contribution to teamwork improvements of the companies. TFL style was found to be the most applied style by leaders of construction companies in Iran compared to transactional leadership by the Iranian construction managers. In another study, during the new product development (NPD) process, using data collected from 184 NPD projects of Chinese high-tech firms, Chi \& Huang (2014) indicated that the impact of team TFL was positively related to team performance. New product development (NPD) team TFL is discovered to positively associated with team performance. Samad (2012) have also claimed that TFL has a significant positive impact on team performance and, on the contrary, transactional leadership has a significant negative effect on team performance. Two dimensions of psychological empowerment were highlighted (Colbert \& Bradley, 2014, Sarver \& Miller, 2014 \& Mason, Griffin, \& Parker, 2014), namely, 
meaning and self-determination which have partial mediation effect in the relationship between TFL and team performance. Another attempt by using 61 R\&D teams from 32 Taiwanese high-technology firms stated that TFL was positively related to positive team goals, which, in turn, positively predicted positive group effect (Fisher, 2013). Positive group affective tone is determined to be positively associated with team performance.

TFL has been shown to have a significant positive relationship with many outcomes that affect performance. TFL and innovation significantly were found to influence organizational performance (Shin, 2017). The author highlighted the importance of TFL and innovation as an advantage and achieving component of internal resources in securing the competitive key organizational performance among Malaysian logistics companies. It is claimed that leaders are transformational in nature and TFL is associated with positive outcomes (Katou, 2015) The author indicated that being an effective leader of a grassroots social services organization may include TFL qualities and behaviors. TFL style was identified to have a direct and positive effect on managerial performance (Soane, Butler, \& Stanton, 2015. Their study demonstrated that a transformational leadership style has a partial indirect effect on managerial performance via three mediators, namely, comprehensive performance measurement system, reward system, and broad scope accounting information. In the same vein, a survey was performed on 339 workers in Korean companies has been conducted based on the moderating effects of genders, on the relationship between transformational leadership and psychological empowerment (Kim \& Kim, 2015). The results showed that gender of the leader did not influence the effectiveness of transformational leadership. Therefore, female transformational leadership is equivalent as male transformational leadership.

A study done in 133 Greek public and private organizations suggested that TFL is positively mediated by organizational, procedural justice, organizational trust integrity, and dependability, with data gathered from added that data from 1,250 employers (Judge \& Piccolo, 2004). In a different setting, effective leadership is believed important to performance in both organizational and sporting arenas (Prenkert \& Ehnfors, 1997). The authors emphasized the effect of TFL on the relationship between leadership effectiveness and performance. These studies presented thus far provide evidence that transformational leadership has a positive relationship with performance. Many scholars found that TFL will increase the performance or effectiveness of organizations. However, there are also contradicting findings on the relationships being identified. A study with data collected from 2008 to 2010 on 560 full-time employees from five local governments in South Korea has proven the findings (Arham, Boucher \& Muenjohn, 2012). Their study was done to investigate the effects of culture type perspectives and procedural justice perceptions on the relationship between TFL and affective commitment as an attitude-related variable. There is a positive relationship among TFL with procedural justice, and organizational affective commitment and also a significant relationship between procedural justice and organizational affective commitment as indicated by the authors. Procedural justice partially mediates the relationship between TFL and organizational affective commitment while hierarchy and market culture type fully moderate the effect of TFL on organizational affective commitment. However, clan and adhocracy culture type did not moderate the effect of TFL on organizational affective commitment. Transformational leadership was failed to predict leader job performance, based on a meta-analysis test (Desa \& Kassim, 2010) . It is supported by another study done who discovered that transformational leadership could not predict organizational effectiveness in a public organization (Arokiasamy, Abdullah, \& Ismail, 2014).

Studies on transformational leadership behaviors of top management team in relation to organizational effectiveness have been ignored (Birasnav, 2014). It is very important as the top management team or the directors are the ones who are responsible for setting strategies of the organization to ensure the organization is functioning effectively. They are responsible for determining the organization's strategic direction, implementing selected strategies, organizing organizational structures and systems, and ensuring effective organizational operations. In addition, all senior management must achieve this broad goal, so they need to build relationships between their employees and their organizations. Many researches in Malaysia have been studying leadership styles concentrated in other areas with positive fndings such as SMEs, resource centre in Universiti Teknologi Malaysia, schools and electrical and electronics sector (Tajasom, 2016; Lowe, Kroeck \& Sivasubramaniam, 1996; Northouse, 2014 \& Menon, 2014). However, not many studies have been done on cooperative movements in Malaysia. Therefore, the following research question is proposed: 
(Q1). What are the perceptions of the cooperatives directors towards their transformational leadership skills?

\section{Methodology}

A set of questionnaire was developed to collect data on transformational leadership and board effectiveness in cooperatives. The respondents of the pilot study are 32 randomly selected board of directors from cooperatives in Selangor. The study was conducted by distributing questionnaires to the directors at their particular organizations.

Then, a five-point Likert scale type was used to evaluate their responses. The data collected was then analyzed using Statistical Package for Social Science version 24. Descriptive statistics such as mean scores for overall perceptions of directors were presented while frequency distribution was used to analyze the percentage on perceptions based on years of service in the organization.

\subsection{Instrument}

The Multifactor Leadership Questionnaire (MLQ) has been used to study leaders at all levels of both public and private organizations in business and industry, the military, and educational and religious institutions, as well as to study organizational measures of performance (Avolio, Bass \& Jung, 1999). It is the most widely used measure of transformational leadership behavior and widely used to collect information regarding TFL behaviors and practices (Walumbwa, Wang, Lawler, \& Shi, 2004 \& Bono, $\&$ Judge, 2003). For this study, the researcher will adapt the questionnaire and use it to measure the self-perceptions of directors of cooperatives on transformational leadership style. As this study focused on evaluating transformational leadership, only 20 items will be used in evaluating transformational leadership dimensions. The MLQ consists of four dimensions of TFL which are (a) idealized attributes and behaviors, (b) inspirational motivation, (c) individualized consideration, and (d) intellectual stimulation. Furthermore, many empirical studies have shown consistently that these dimensions are highly correlated and that they reflect a higher-order construct of transformational leadership [45]. This is consistent with theoretical developments and empirical studies on transformational leadership theory (Yukl, 1999; Kark, Shamir, \& Chen, 2003 \& Walumbwa \& Lawler, 2003).

\section{Results and discussion}

In this study, number of male directors is slightly higher compared to female students with 18 male directors and 14 female directors as shown in Table 2.

Table 2. Number of directors according to gender.

\begin{tabular}{|l|l|l|l|l|}
\hline Valid & & Frequency & Percent & Cumulative Percent \\
\cline { 2 - 5 } & Male & 18 & 56.3 & 56.3 \\
\cline { 2 - 5 } & Female & 14 & 43.8 & 100.0 \\
\cline { 2 - 5 } & Total & 32 & 100.0 & \\
\hline
\end{tabular}

\subsection{Overall perceptions on transformational leadership}

Table 3 shows the some of the highest and lowest mean scores for directors' perceptions towards their transformational leadership attributes. On the lower note, directors perceived their lowest score of 2.88 out of 5.0 on "I go beyond self-interest for the good of the group" which suggests that they are reluctant to sacrifice their self-interest for the sake of the group. Second lowest score is 3.56 out of 5.0 on "I talk about my most important values and beliefs". It suggests that directors do not talk about their important values and beliefs much to others. Third lowest score is 3.91 out of 5.0 on I instil pride in others for being associated with me. It suggests that directors do not instill pride in others which may affect the quality of work and motivation. By constructively helping people stretch beyond their current abilities, knowledge, and/or level of self-confidence, it helps them to become more valuable to 
the organization and to themselves. These findings are in line with previous studies done by Laitinen (2016) , Judge \& Piccolo (2004) and Prenkert \& Ehnfors (1997) which discussed on the negative effect of transformational leadership.

On the higher score of the means, directors perceived their highest score of 4.72 out of 5.0 on "I consider an individual as having different needs, abilities, and aspirations from others". It implies that directors are being considerate in accommodating the different needs, abilities and aspirations of other people. Second highest score is 4.59 out of 5.0 on "I help others to develop their strengths". It suggests that directors are willing to help others to bring out their strengths from within. Third highest score is 4.41 on "I treat others as individuals rather than just a member of a group". It suggests that directors give attentions to other members' personal needs rather than generalized their needs as a whole.

Table 3. Mean scores for perceptions of the directors towards their transformational leadership attributes.

\begin{tabular}{|l|l|l|}
\hline Statement & N & Mean \\
\hline I instil pride in others for being associated with me. & 32 & 3.91 \\
\hline I go beyond self-interest for the good of the group. & 32 & 2.88 \\
\hline I act in ways that build others' respect for me. & 32 & 4.03 \\
\hline I emphasize the importance of self- confidence. & 32 & 4.19 \\
\hline I talk about my most important values and beliefs & 32 & 3.56 \\
\hline $\begin{array}{l}\text { I specify the importance of having a strong sense of } \\
\text { purpose }\end{array}$ & 32 & 4.19 \\
\hline I pay attention to my decision results. & 32 & 4.19 \\
\hline $\begin{array}{l}\text { I emphasize the importance of having a collective } \\
\text { sense of mission. }\end{array}$ & 32 & 4.19 \\
\hline I talk optimistically about the future. & 32 & 4.25 \\
\hline $\begin{array}{l}\text { I talk enthusiastically about what needs to be } \\
\text { accomplished }\end{array}$ & 32 & 4.13 \\
\hline I articulate a compelling vision of the future. & 32 & 4.19 \\
\hline I express confidence that goals will be achieved. & 32 & 4.19 \\
\hline $\begin{array}{l}\text { I re-examine critical assumptions to question whether } \\
\text { they are appropriate. }\end{array}$ & 32 & 4.00 \\
\hline I seek differing perspectives when solving problems & 32 & 4.00 \\
\hline $\begin{array}{l}\text { I get others to look at problems from many different } \\
\text { angles }\end{array}$ & 32 & 4.00 \\
\hline $\begin{array}{l}\text { I suggest new ways of looking at how to complete } \\
\text { assignments. }\end{array}$ & 32 & 3.94 \\
\hline I take time instruct others. & 32 & 4.25 \\
\hline $\begin{array}{l}\text { I treat others as individuals rather than just a member } \\
\text { of a group. }\end{array}$ & 32 & 4.41 \\
\hline $\begin{array}{l}\text { I consider an individual as having different needs, } \\
\text { abilities, and aspirations from others. }\end{array}$ & 32 & 4.72 \\
\hline I help others to develop their strengths. & 32 & 4.59 \\
\hline
\end{tabular}

\section{Conclusion}

It is believed that transformational leadership plays a major role in cooperative movements performance. Findings from this study showed that most of the cooperatives directors perceived high on their transformational leadership styles, without them realizing. Although there are low scores on few of the items, they scored high in most of the other survey questions. This paper is a pilot study on the perceptions of transformational leadership style among Malaysian cooperatives board of directors. The literature on transformational leadership has shown that transformational leaders help to inspire followers by increasing their motivations and boost their performance. It is hoped that the findings from this study will contribute to a better understanding of board effectiveness and gives remarkable insights into key considerations for appointing directors in emerging markets such as Malaysia. Findings of this study are also hoped to help the cooperative movement industry to increase their performance to achieve the national vision as a driver of the cooperative excellence to contribute towards national development. Future studies may focus on the impact of transformational leadership 
style on cooperatives' performances as well as proposing other predictors such as work ethics, work culture and other variables.

\section{References}

Akhavan Tabassi, A., Ramli, M., Hassan Abu Bakar, A., \& Hamid Kadir Pakir, A. (2014).

Transformational leadership and teamwork improvement: the case of construction firms. Journal of Management Development, 33(10), 1019-1034. http://doi.org/10.1108/JMD-01-2012-0003

Arham, A. F., Boucher, C. \& Muenjohn, N. Does Leadership Matter? A Case of Malaysian SMEs (2012). Proceedings of 19th International Business Research Conference, 2012

Bono, J. E., \& Judge, T. A. (2003). Self-concordance at work: Toward understanding the motivational effects of transformational leaders. Academy of Management Journal, 46, 554 - 571

Arokiasamy, A. R. A., Abdullah, A. G. K., \& Ismail, A. (2014). Correlation between cultural perceptions, leadership style and ICT usage by school principals in Malaysia. Turkish Online Journal of Educational Technology, 13(3), 27-40. http://doi.org/10.1016/j.sbspro.2015.01.478

Tajasom, A. (2016). thesis - TFL - mediating - team cohesion. Retrieved from http://eprints.usm.my/32081/1/ADEL_TAJASOM_24(NN).pdf

Avolio, B. J., Bass, B. M., \& Jung, D. I. (1999). Re-examining the components of transformational and transactional leadership using the Multifactor Leadership Questionnaire. Journal of Occupational and Organizational Psychology Bass \& Avolio Van Muijen \& Koopman House \& PodsakoV, 72, 441-462. http://doi.org/10.1348/096317999166789.

Avolio, B.J., Yammarino, F.J. (Eds.). (2002). Transformational and charismatic leadership: The road ahead. (V.2). Amsterdam: JAI- Elsevier Science.

Bass, B.M. (1994). “Transformational leadership and team and organizational decision making”, in

Bass, B. and Avolio, B. (Eds), Improving Organizational Effectiveness ThroughTransformational Leadership, Sage, Thousand Oaks, CA, pp. 104-20.

Bass, B. M. (1998). Transformational leadership: Industry, military, and educational impact. Mahwah, NJ: Erlbaum.

Bass, B. M., \& Riggio, R. E. (2006). Transformational leadership (2nd ed.). Transformational Leadership (2nd Ed.), 282. http://doi.org/10.1002/1521-3773(20010316)40:6<9823::AIDANIE9823>3.3.CO;2-C

Birasnav, M. (2014). Relationship between transformational leadership behaviors and manufacturing strategy. International Journal of Organizational Analysis, 22(2), 205-223.

http://doi.org/10.1108/IJOA-10-2011-0520

Boehm, S. A., Dwertmann, D. J. G., Bruch, H., \& Shamir, B. (2015). The missing link? Investigating organizational identity strength and transformational leadership climate as mechanisms that connect CEO charisma with firm performance. Leadership Quarterly, 26(2), 156-171. http://doi.org/10.1016/j.leaqua.2014.07.012

Brouer, R. L., Chiu, C. C., \& Wang, L. (2016). Political skill dimensions and transformational leadership in China. Journal of Managerial Psychology, 31(6), 1040-1056.

http://doi.org/10.1108/JMP-05-2014-0166 
Chen, A. S., Bian, M., \& Hou, Y.-H. (2015). Impact of transformational leadership on subordinate's EI and work performance. Personnel Review, 44(4), 438-453. http://doi.org/10.1108/PR-09-2012-0154

Chi, N. W., \& Huang, J.-C. (2014). Mechanisms Linking Transformational Leadership and Team Performance: The Mediating Roles of Team Goal Orientation and Group Affective Tone. Group \& Organization Management, 39(3), 300-325. http://doi.org/10.1177/1059601114522321

Colbert, A. M. Y. E., \& Bradley, B. H. (2014). Personality and leadership composition in top management teams : implications for organizational effectiveness. Personnel Psychology, 351-387. http://doi.org/10.1111/peps.12036

Desa, K. N. M., \& Kassim, N. A. (2010). Transformational Leadership Enhances Customer Satisfaction. PPM, 4.

Economic Planning Unit. (2015). Strengthening Infrastructure to Support Economic Expansion. Rancangan Malaysia Kesebelas (Eleventh Malaysia Plan) : 2016-2020. Retrieved from http://rmk11.epu.gov.my/book/eng/Elevent-Malaysia-Plan/RMKe-11 Book.pdf

Feng, C., Huang, X., \& Zhang, L. (2016). A multilevel study of transformational leadership, dual organizational change and innovative behavior in groups. Journal of Organizational Change Management, 29(6), 855-877. http://doi.org/10.1108/JOCM-01-2016-0005

Fisher, L. (2013). Transformational leadership among grassroots social service organizations. Community Development, 44(3), 292-304. http://doi.org/10.1080/15575330.2013.803490

Judge, T. a, \& Piccolo, R. F. (2004). Transformational and transactional leadership: a meta-analytic test of their relative validity. The Journal of Applied Psychology, 89(5), 755-68. http://doi.org/10.1037/0021-9010.89.5.755

Humphreys, J. H., \& Einstein, W. O. (2003). Nothing New Under the Sun: Transformational Leadership from a Historical Perspective. Management Decision, 41 (1), 85-95.

Kark, R., Shamir, B., \& Chen, G. (2003). The two faces of transformational leadership: Empowerment and dependency. Journal of Applied Psychology, 88, 246-255

Katou, A. A. (2015). Transformational leadership and organisational performance Three serially mediating mechanisms. Journal of Managerial Psychology, Vol. 37(3), 329-353.

http://doi.org/10.1016/S0363-8111(96)90097-1

Kim, H., \& Kim, J. (2015). A cross-level study of transformational leadership and organizational affective commitment in the Korean Local Governments: Mediating role of procedural justice and moderating role of culture types based on competing values framework. Leadership, 11(2), 158-185. http://doi.org/10.1177/1742715013514880

Levrau, A., \& Van den Berghe, L. (2013). Perspectives on the decision-making style of the board chair. International Journal of Disclosure and Governance, 10(2), 105-121. http://doi.org/10.1057/jdg.2013.18

Lowe, B. K. B., Kroeck, K. G., \& Sivasubramaniam, N. (1996). Effectiveness Correlates of Tranformational and Transactional Leadership: A Meta-Analytis Review of The MLQ Literature. The Leadership Quarterly, 7(3), 385-425. http://doi.org/10.1016/S1048-9843(96)90027-2

Mahalinga Shiva, M. S. A., \& Suar, D. (2012). Transformational Leadership, Organizational Culture, Organizational Effectiveness, and Programme Outcomes in Non-Governmental Organizations. Voluntas, 23(3), 684-710. http://doi.org/10.1007/s11266-011-9230-4 
Mason, C., Griffin, M., \& Parker, S. (2014). Transformational leadership development. Leadership \& Organization Development Journal, 35, 174-194. http://doi.org/10.1108/LODJ-05-2012-0063

Mattar, D. M. (2016). Lebanese cherishing a transformational educational leader. International Journal of Educational Management. http://doi.org/10.1108/IJEM-06-2015-0085

Md. Yusof, A.S. (2017, Nov 17). "Bank Rakyat's Cooperatives emerged as the world's largest 118th cooperative," Utusan Melayu. Retrieved from http://www.utusan.com.my/berita/nasional/koperasibank-rakyat-muncul-koperasi-ke-118-terbesar-dunia-1.554700\#ixzz5ME3v6dO1

Menon, M.E. (2014). The relationship between transformational leadership, perceived leader effectiveness and teachers' job satisfaction. Journal of Educational Administration, 52(4), 509-528. http://doi.org/10.1108/JEA-01-2013-0014

Mesterova, J., Prochazka, J., Vaculik, M., \& Smutny, P. (2015). Relationship between Self-Efficacy, Transformational Leadership and Leader Effectiveness. Journal of Advanced Management Science, 3(2), 109-122. http://doi.org/10.12720/joams.3.2.109-122

Nguyen, T. T., Mia, L., Winata, L., \& Chong, V. K. (2017). Effect of transformational-leadership style and management control system on managerial performance. Journal of Business Research, 70(August), 202-213. http://doi.org/10.1016/j.jbusres.2016.08.018

Northouse, P. (2004). Leadership: Theory and practice (3rd ed.). Thousand Oaks, CA: Sage Publications.

Pieterse-Landman, E. (2012). The relationship between transformational leadership, employee engagement, job characteristics and intention to quit. Journal of Chemical Information and Modeling, 53(March), 160. http://doi.org/10.1017/CBO9781107415324.004

Prenkert, F. \& Ehnfors, M. (1997). A measure of organizational effectiveness in nursing management in relation to transactional and transformational leadership: a study in a Swedish hospital. Journal of Nursing Management, 5(5), 279-287.

Rao, A. S., \& Abdul K, W. (2015). Impact of transformational leadership on team performance: an empirical study in UAE. Measuring Business Excellence, 19(4), 30-56. http://doi.org/10.1108/MBE07-2014-0022

Samad, S. (2012). The Influence of Innovation and Transformational Leadership on Organizational Performance. Procedia - Social and Behavioral Sciences, 57, 486-493. http://doi.org/10.1016/j.sbspro.2012.09.1215

Sarver, M. B. \& Miller, H. (2014). Police chief leadership: styles and effectiveness. Policing: An International Journal of Police Strategies \& Management, 37(1), 126-143. https://doi.org/10.1108/PIJPSM-03-2013-0028

Shin, S. K. M. (2017). The effectiveness of transformational leadership on empowerment: the roles of gender and gender dyads. Cross Cultural \& Strategic Management, 24(2).

Soane, E., Butler, C., \& Stanton, E. (2015). Followers' personality, transformational leadership and performance. Sport, Business and Management: An International Journal, 5(1), 65-78. http://doi.org/10.1108/SBM-09-2011-0074

Sun, W., Xu, A., \& Shang, Y. (2014). Transformational leadership, team climate, and team performance within the NPD team: Evidence from China. Asia Pacific Journal of Management, 31(1), 127-147. http://doi.org/10.1007/s10490-012-9327-3 
Tafvelin, S. (2013). The Transformational Leadership Process: Antecedents, Mechanisms, and Outcomes in the Social Services. Mechanisms, and Outcomes in the Social Services, Umeå, Department of Psychology.

Tulus, R. \& Iyer, B. (2015). Co-operatives and the ASEAN economic blueprint : call for greater Co-op engagement and visibility.

Walumbwa, F. O., \& Lawler, J. J. (2003). Building effective organizations: Transformational leadership, collectivist orientation, work-related attitudes, and withdrawal behaviors in three emerging economies. International Journal of Human Resource Management, 14, 1083 - 1101

Walumbwa, F.O., Wang, P., Lawler, J.J., \& Shi, K. (2004). The role of collective efficacy in the relations between transformational leadership and work outcomes. Journal of Organizational and Occupational Psychology, 77, 515-53

Yaghoubipoor, A., Ong, P. T. and Ahmed, E. M. (2013). Impact of the relationship between transformational and traditional leadership styles on Iran's automobile industry job satisfaction. World Journal of Entrepreneurship, Management and Sustainable Development, 9(1), 14-27. http://doi.org/10.1108/20425961311315692

Yukl, G. (1999) An Evaluation of the Conceptual Weaknesses in Transformational and Charismatic. Leadership Quarterly. 10(2), 285-305.

Yukl, G. (1989). Leadership in organizations, second edition. Englewood Cliffs, NJ: PrenticeHall. 